\title{
TROPHIC RELATIONSHIPS AND STATUS OF RESERVOIRS WITH AND WITHOUT OCCURRENCE OF DREISSENA SSP. (MOLLUSCA, BIVALVIA) BUILT ON BULGARIAN DANUBE RIVER TRIBUTARIES
}

Roumen KALCHEV*, Mihaela BESHKOVA* and Hristina KALCHEVA *

* Bulgarian Academy of Science, Institute of Biodiversity and Ecosystem Research, Tsar Osvoboditel Boulevard 1, Sofia, BG-1000, Bulgaria, roumenkalchev@hotmail.com, beshkova_m@yahoo.com, hristinakalcheva@yahoo.com

DOI: 10.1515/trser-2015-0076

KEYWORDS: aquatic cormophytes, paludal cormophytes, chorology.

\section{ABSTRACT}

The trophic status and relationships between Secchi depth transparency (SD) chlorophyll-a (CHL) and total phosphorus (TP) concentrations from nine non-infested and five infested areas with invasive alien species, Dreissena ssp. reservoirs, situated on the Bulgarian Danube River tributaries were studied. The trophic status index (TSI) values after Carlson (1977), and showed statistically significant differences for all three variables between infested and non-infested reservoirs. The three linear regression equations between SD x CHL, CHL x TP and SD x TP were statistically significant for the group of non-infested reservoirs, while in the infested reservoirs only the SDxCHL regression was statistically significant for $\mathrm{P}<0.05$. Our results showed that the Dreissena invasion destroyed the linear relationship between CHL x TP and SD x TP and seems to affects the accurate application of Carlson TSI.

RESUMEN: Las relaciones tróficas y el estado de los embalses con y sin existencia de Dreissena ssp. (Mollusca, Bivalvia) basado en los afluentes búlgaros del Río Danubio.

El estado trófico y las relaciones entre la transparencia-profundidad del disco de Secchi (SD), concentraciones de clorofila-a (CHL) y fósforo total (TP) de nueve embalses no infestados y cinco infestados con a especie exóticas invasoras Dreissena ssp. fueron estudiados. Se estudiaron los embalses situados en los afluentes búlgaros del río Danubio. Los valores de índice de estado trófico (TSI) según Carlson (1977) mostraron diferencias estadísticamente significativas para las tres variables entre embalses infestados y no infestados. Las tres ecuaciones de regresión lineal entre SD x CHL, CHL x TP y SD x TP fueron estadísticamente significativas para el grupo de los embalses no infestadas, mientras que en los embalses infestados solamente la regresión SDxCHL fue estadísticamente significativa con $\mathrm{P}<0,05$. Nuestros resultados mostraron que la invasión de Dreissena destruyó la relación lineal entre CHL x TP y SD x TP y parece que afecta a la aplicación precisa de Carlson TSI.

REZUMAT: Relații trofice și starea lacurilor de acumulare cu și fără populații de Dreissena ssp. (Mollusca, Bivalvia) constituite pe afluenții dunăreni de pe teritoriul bulgăresc.

S-a studiat starea trofică și relațiile între transparența măsurată cu discul Secchi (SD) și concentrațiile de clorofilă-a (CHL) şi de fosfor total (TP) din nouă lacuri de acumulare neinfestate şi cinci infestate cu specia invazivă Dreissena ssp., situate pe afluenții de pe malul bulgăresc al Dunării. Valorile indicelui de eutrofizare după Carlson (1977) au variat statistic semnificativ în cazul tuturor celor trei variabile de la un lac la altul. Cele trei ecuații de regresie liniară între SD x CHL, CHL x TP and SD x TP s-au corelat semnificativ din punct de vedere statistic pentru grupul de lacuri neinfestate, în timp ce în cazul lacurilor infestate numai regresia SD x CHL a prezentat semnificație statisică cu $\mathrm{P}<0,05$. Rezultatele noastre demonstrează că invazia de Dreissena ssp. a anihilat relația liniară între CHLxTP și SDxTP și pare să afecteze aplicarea corectă a indicelui de eutrofizare Carlson. 


\section{INTRODUCTION}

The substantial increase during recent decades in mobility and all kinds of contact of mankind around the globe is leading to an intentional and non-intentional fast spreading of biological species far beyond their natural areal. The Danube River is not an exception (Bănăduc et al., 2016).

Those alien species which are threatening the biodiversity of invaded native ecosystems are considered invasive (IUCN, 2000).

Some invasive alien species like Dreissena ssp. are also able to strongly affect not only the biodiversity but also the habitat and functioning of aquatic ecosystems. Through this, they are affecting relationships and metrics developed for the estimation of ecological status and implementation of the Water Framework Directive of EC (Qualls et al., 2007; Arndt et al., 2009; De Winton et al., 2012).

Until now, the widely used trophic state index (TSI) developed by Carlson (1977), for trophic status estimation of standing aquatic ecosystems was still not tested if its applicability is also influenced by invasive alien species; despite the fact that the relationship underlying for TSI between chlorophyll-a (CHL) and total phosphorus (TP) was reported to be strongly affected by Dreissena ssp. (Qualls et al., 2007; Atalah et al., 2010). Therefore, we have set our goal to study the effect of Dreissena ssp. occurrence on the three SD x CHL, CHL x TP and SD x TP relationships, which are fundamental for derivation of TSI of Carlson (1977).

\section{MATERIAL AND METHODS}

Measurements of water column transparency by Secchi disc (SD) chlorophyll-a (CHL) and total phosphorus (TP) concentrations from a total of 14 freshwater reservoirs situated in the Danube River catchment on Bulgarian territory were available for testing the effect of Dreissena's ssp. occurrence.

There are two main data sources providing the mentioned measurements. The first one was the publication of Tosheva, Traykov (2012), consisting of data collected between June and September, 2009-2011. The second one was represented by the three own extensive sampling campaigns on five stations of Ogosta Reservoir in the same period. The already published list of reservoirs with and without Dreissena ssp. by Kalchev et al. (2014), helps us to identify the two groups.

The group without Dreissena ssp. includes eight reservoirs: Barzina Asparuhov, Yastrebino, Kovachitsa, Pancharevo, Kula, Poletkovtsi Chr. Smirnenski; the data for which are available in Tosheva, Trykov (2012). The data of the ninth Rasovo Reservoir without Dreissena ssp. originates from our own accidental measurements carried out in 2015. The group with Dreissena ssp. contains five reservoirs, data for four of which (Telish, Rabisha, Gorni Dabnik, Stoykovtsi) was obtained from Tosheva, Trykov (2012), while Ogosta Reservoir was presented by 15 own and one additional set of measurements was also taken from Tosheva, Traykov (2012) (Fig. 1).

The three trophic variables (SD, CHL, and TP) despite originating from two different sources, were measured by means of the same methods (CHL by ISO 10260 (1992) and TP by MERCK products - kits and Nova 60 photometer both manufactured by MERCK) which makes them good by comparison.

The formulas published by Carlson (1977), served for calculation of trophic state indices for SD, CHL, and TP. The statistical analysis was carried out by PAST statistical package (Hammer et al., 2001). 


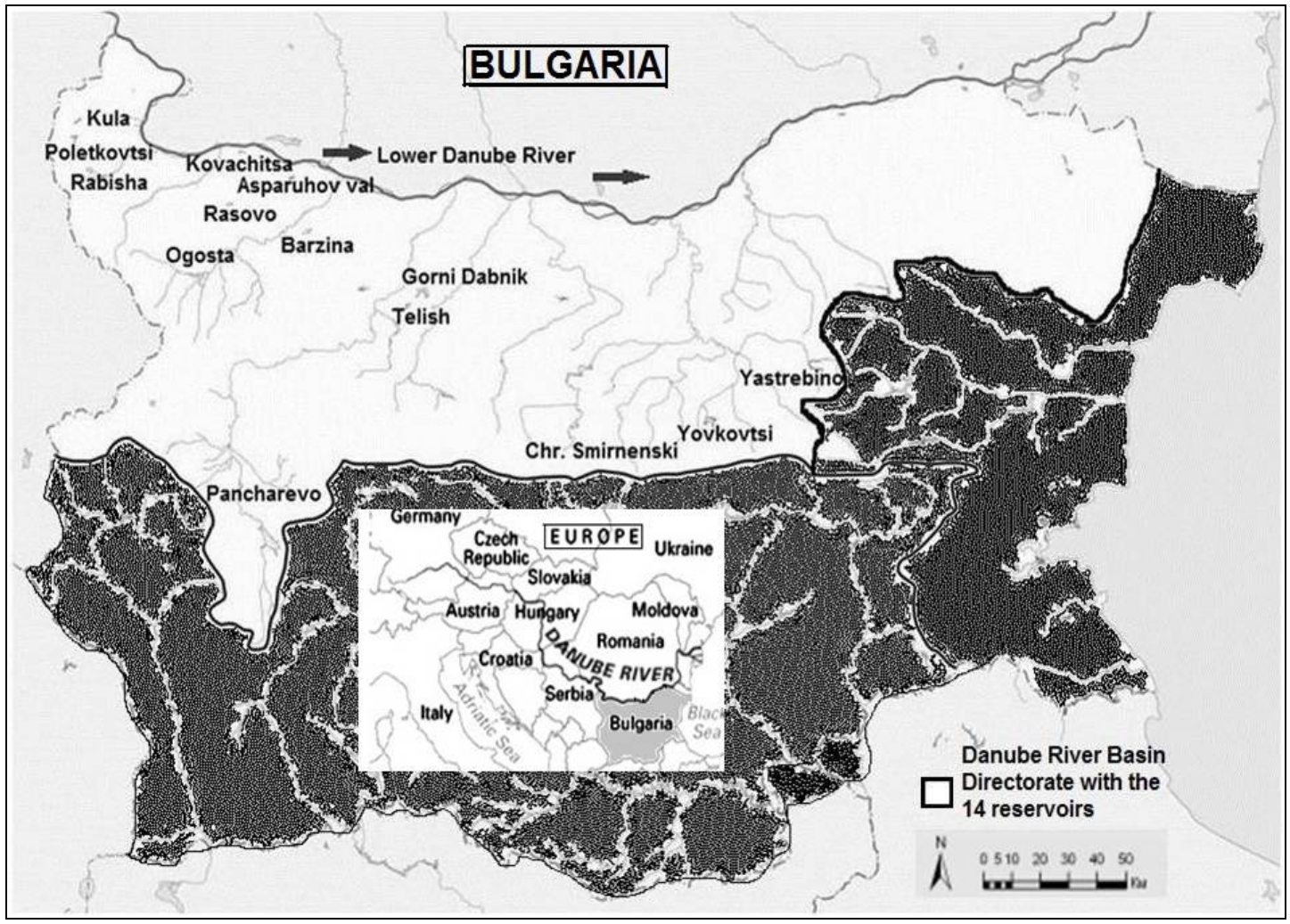

Figure 1: Bulgaria map with catchment area of the Danube River on Bulgarian territory and distribution of investigated reservoirs.

\section{RESULTS AND DISCUSSION} reservoirs

Mean value differences of trophic variables between invaded and non-invaded

The most investigated reservoirs are scattered in the north-western part of Bulgaria (Fig. 1).

Because of different standard deviations, unknown frequency distribution and a limited number of samples of the compared two groups, we applied a non-parametric test of Kruskal-Wallis which showed an already known picture (Kalchev et al., 2014), with statistically significant lower CHL and higher SD values in infested than in non-infested waters.

However, in this specific study, for original TP values the Kruskal-Wallis test did not show statistically significant differences between infested and in non-infested reservoirs (Fig. 2). 


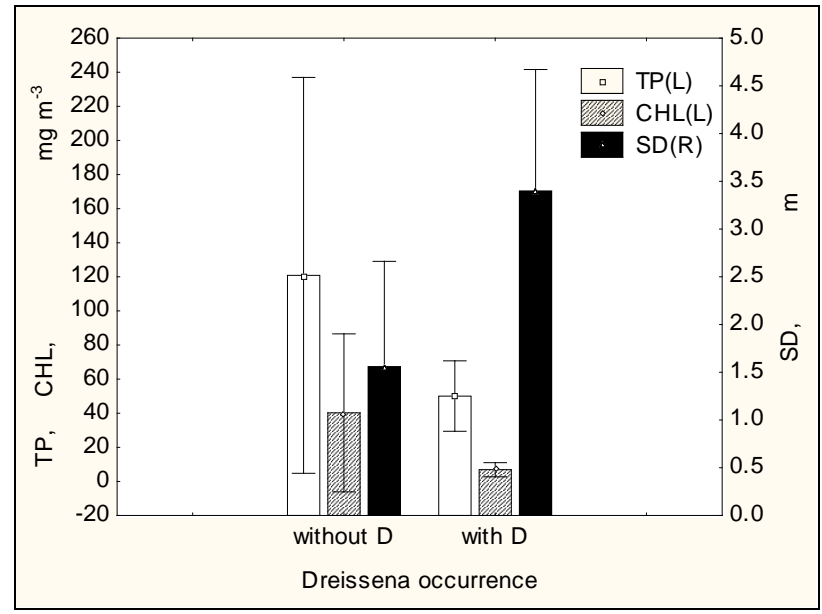

Figure 2: Arithmetic means and standard deviations of total phosphorus (TP), chlorophyll-a (CHL) and water column transparency (SD) in reservoirs with and without Dreissena ssp. The comparison of infested and non-infested with Dreissena ssp. waters by means of

Kruskal-Wallis delivered the following results: TP: KW-H $(1 ; 29)=1.564 ; \mathrm{p}=0.2111$, CHL: $\mathrm{KW}-\mathrm{H}(1 ; 29)=10.8889 ; \mathrm{p}=0.0010$, SD: $\mathrm{KW}-\mathrm{H}(1 ; 28)=9.4629 ; \mathrm{p}=0.0021$.

The calculation of TSI by removing a possible lack of normal distribution and delivering equal standard deviations makes the comparison of mean values by parametric t-tests possible, which now shows a significant difference between infested and non-infested reservoirs for all three compared TSI (Fig. 3).

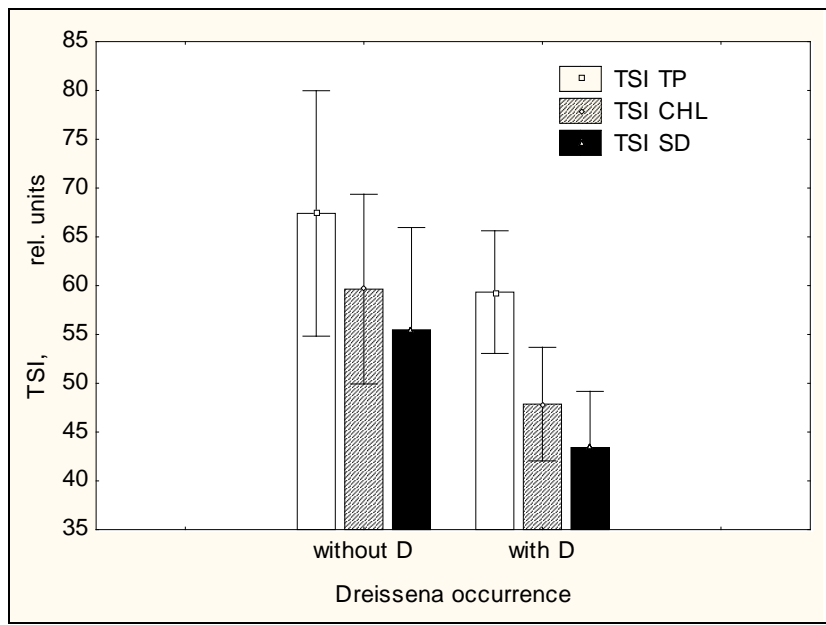

Figure 3: Arithmetic means and standard deviations of trophic state indices (TSI) for TP, CHL and SD in reservoirs with and without Dreissena ssp. The comparison of infested and non-infested with Dreissena ssp. waters by means of t-test for independent samples delivered the following results: for TSI $\mathrm{TP}_{\mathrm{TP}}$ : $\mathrm{t}$-value $=2.64 ; \mathrm{p}<0.02$, $\mathrm{TSI}_{\mathrm{CHL}}$ : $\mathrm{t}$-value $=4.42$; $\mathrm{p}<0.0002$, TSI $_{\mathrm{SD}}$ : $\mathrm{t}-\mathrm{value}=4.32 ; \mathrm{p}<0.0002$. 
The three TSI mean values of infested reservoirs demonstrate lower trophicity than the non-infested. A weak decrease, significant for $\mathrm{P}<0.01$ in epilimnion and an insignificant increase of soluble reactive phosphorus in hypolimnion of Zhrebchevo Reservoir after the Dreissena ssp. invasion (Kalchev et al., 2013) seems to be a result of Dreissena ssp. which caused a shift of big share of energy and matter flow from pelagic to benthic pathways.

However, the results of Qualls et al. (2007) showed no significant differences between concentrations of pre and post invasion periods in the Lower Green Bay of lake Michigan, USA.

Moreover, if they include the measured high TP values of the last two years in statistical analyses, then statistically significant differences in favor of post-invasion period appeared. Strayer et al. (1999), also reported an increase of soluble reactive phosphorus after the Dreissena ssp. invasion.

On one hand this TP increase might be attributed to outer sources (Qualls et al., 2007), but on the other, Strayer et al. (1999), explained it by a reduced uptake of phytoplankton.

The differences between TSI mean values of the three variables on figure 3 could be applied for evaluation of prevailing phytoplankton limitation conditions in the two reservoir groups, which are showing similar behavior in infested and non-infested with Dreissena ssp. waters. Thus, the negative difference between TSI means of CHL and TP indicates that most reservoirs of both groups seem to be non-phosphorus limited. On the other hand, the positive difference between TSI means of CHL and SD let us suppose in most cases that the lack of phytoplankton limitation is caused by non-algal turbidity.

\section{reservoirs}

Regression differences between trophic variables in invaded and non-invaded

All three studied variables (CHL, SD, and TP) are considered almost similar in power to determine the trophic status of standing water bodies. Therefore, Carlson (1977), used the strong mutual correlations between them to derive his trophic state index applied worldwide for estimation of trophic status of standing surface water bodies (Jarosiewicz et al., 2011; Sheela et al., 2011; Tosheva and Traykov, 2012).

As already shown above on figure 1 and 2 and in literature sources (Idrisi et al., 2001; Kalchev et al., 2013, 2014), the CHL and SD variables are changing almost in synchrony as a result of the Dreissena ssp. invasion, while the TP does not. This tendency is confirmed when the three variables are correlated with each other successively. The lnCHL and $\operatorname{lnSD}$ are showing statistically significant linear regression equations in both groups, (invaded and noninvaded reservoirs). Despite the regression slopes, the groups are also not statistically deferent; there is a clear decrease of percent variation of $\operatorname{lnSD}$ explained by $\operatorname{lnCHL}$ in the group of infested reservoirs $\left(R^{2}=0.2761\right)$ than in non-infested ones $\left(R^{2}=0.6687\right)$ (Fig. 4). 


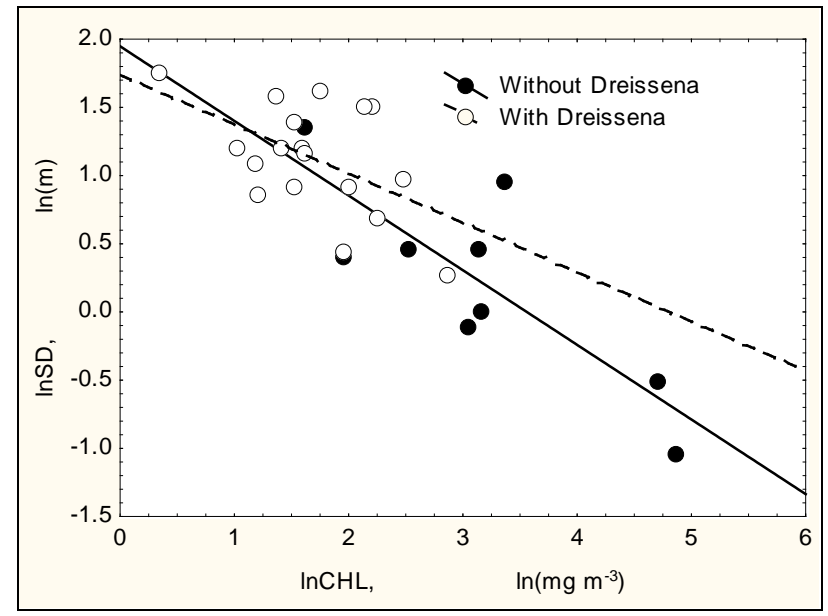

Figure 4: Linear regression equations between natural logarithm values of CHL and SD in reservoirs without Dreissena ssp. $\operatorname{lnSD}=1.948-0.5472 * \operatorname{lnCHL~} r^{2}=0.6687 ; \mathrm{r}=-0.8177$; $\mathrm{p}=0.0071$; and with Dreissena ssp. $\operatorname{lnSD}=1.7371-0.3613^{*} \operatorname{lnCHL~} \mathrm{r}^{2}=0.2761$;

$$
\mathrm{r}=-0.5254 ; \mathrm{p}=0.0251 \text {. }
$$

The next regression between $\operatorname{lnCHL}$ and $\operatorname{lnTP}$ (Fig. 5) strengthens this tendency. The regression slopes in the two groups are again not statistically different, but the slope of regression equation of infested reservoirs was slightly beyond the significance border and the $\mathrm{R}^{2}=0.1828$ gets lower, while that of non-invaded remains almost unchanged $\left(\mathrm{R}^{2}=0.6176\right)$.

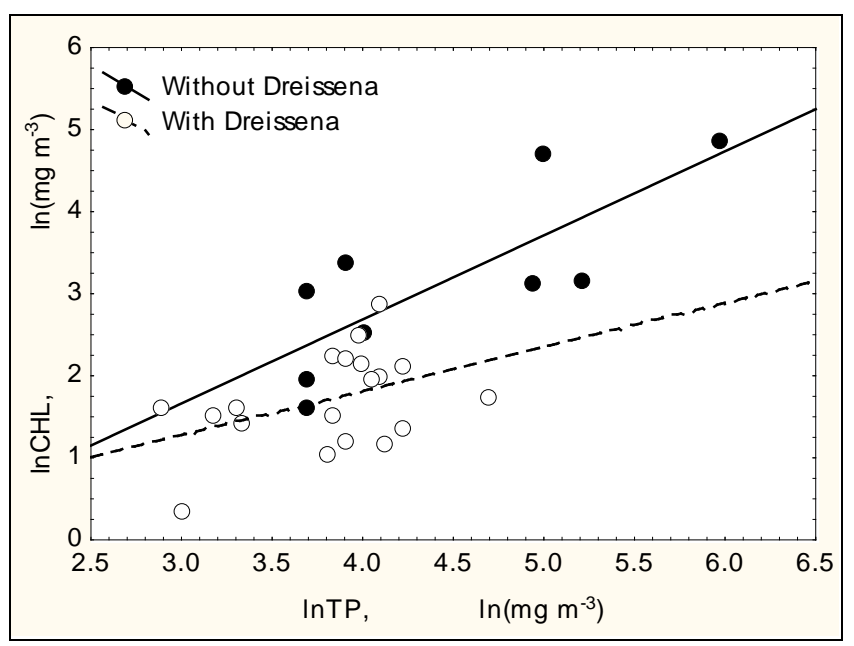

Figure 5: Linear regression equations between natural logarithm values of CHL and TP in reservoirs without Dreissena ssp. $\operatorname{lnCHL}=-1.4099+1.0243 * \ln \mathrm{TP}^{2}=0.6176$; $\mathrm{r}=0.7858 ; \mathrm{p}=0.0121$; with Dreissena ssp.; $\operatorname{lnCHL}=-0.3331+0.5371 * \ln \mathrm{TP} \mathrm{r}^{2}=0.1828$;

$$
r=0.4275 ; p=0.0679 \text {. }
$$


The third regression equation between $\operatorname{lnSD}$ and $\operatorname{lnTP}$ is again highly significant for the group of non-invaded reservoirs, while in the invaded ones it does not achieve a statistically significant level (Fig. 6). The percentage explained the variation of lnSD by $\operatorname{lnTP}$ in the group of infested reservoirs as it decreases further $\left(\mathrm{R}^{2}=0.0332\right)$ and despite the continuous decrease of the same percentage for non-infested $\left(\mathrm{R}^{2}=0.5464\right)$; the difference between them becomes bigger than previous regressions.

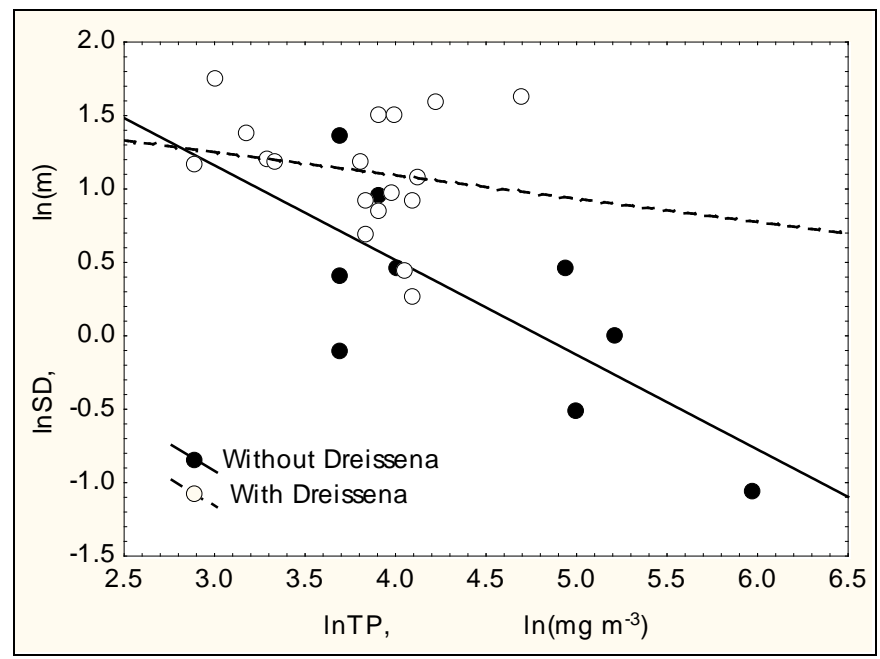

Figure 6: Linear regression equations between natural logarithm values of SD and TP in reservoirs without Dreissena ssp. $\operatorname{lnSD}=3.095-0.6448 * \operatorname{lnTP} r^{2}=0.5464$; $r=-0.7392 ; \mathrm{p}=0.0229$; and with Dreissena ssp. $\operatorname{lnSD}=1.7274-0.1587 * \operatorname{lnTP} r^{2}=0.0332$;

$$
\mathrm{r}=-0.1822 ; \mathrm{p}=0.4692 \text {. }
$$

Qualls et al. (2007), reported similar changes under the influence of Dreissena ssp. on the linear regression between log-values of CHL and TP. At low and average Dreissena ssp. densities $\left(5.6,396 \mathrm{ind} / \mathrm{m}^{-2}\right)$ the regression equations between CHL and TP data of pre- and post-invasion periods remain statistically significant; while at high densities $\left(581 \mathrm{ind} / \mathrm{m}^{-2}\right)$ the relationship of the post-invasion period became insignificant. Simultaneously, with an increasing Driessena ssp. density, the percentage of CHL explained of TP by linear regression decreases in the post-invasion period gradually from 0.32 to 0.18 and finally to 0.01 ; while that of pre- invasion remains approximately unchanged. Atalah et al. (2010), confirmed the destructive effect of the Dreissena ssp. invasion on important relationships between TP and several metrics of zoobenthos serving as indicators for ecological status. Obviously, the invasion of such species strongly impacts the functioning and biodiversity of the area and questions the applicability of approved methodologies for measuring the trophic and ecological status of aquatic ecosystems. Atalah et al. (2010), concluded that separate metrics have to be developed for invaded and non-invaded aquatic ecosystems. However in the case of Driessena ssp. invasion, this approach seems difficult because as shown by Qualls et al. (2007), the invader influence strongly depends on its density. First, the density is rarely presented in the studies due to difficult and time consuming measurements and second (especially in reservoirs), the density of this mussel inhabiting the upper three to four $\mathrm{m}$ depth layers is variable as a result of frequent and considerable water level fluctuations characteristic for this water. Unfortunately, until now there are no investigations published dealing with adaptations 
of Carlson's TSI to the Dreissena ssp. influence, and the only reasonable recommendation would be when applying the TSI to take care of the Dreissenidae sp. occurrence. Our limited number of samples involved in analyses indicates that the usage of TP for calculation of TSI is risky if Dreissena ssp. is present. As already stated, the Dreissena ssp. caused a big shift of energy and matter flow from pelagic into benthic pathways (Strayer et al., 1999), and therefore values of pelagic space variables are getting less informative for characterization of trophic status of the whole ecosystem. Thus, CHL of phytoplankton and SD seem to remain more restricted to pelagic space while TP is increasingly related to benthic processes and pathways, and as a result seem to correlate less strongly with pelagic characteristics under the Dreissena ssp. influence. Further investigations will show that if the widely used, trophic state index of Carlson could be successfully adapted to challenges caused by strong Dreissena ssp. invaders.

\section{CONCLUSIONS}

The trophic status determination by means of index of Carlson has brought a considerable progress in the process of classification of aquatic ecosystems by reducing it to determination of a few easy to measure variables and applying them not only for estimation of trophic status but also for studying conditions limiting the phytoplankton growth. Initially developed for only three variables (SD, CHL, and TP) soon it was supplemented with total nitrogen data accounting for increasing frequency of nitrogen limitation in aquatic ecosystems. Now, in recent days the application of Carlson TSI, like of many other similar metrics used for status estimation of aquatic ecosystems, are confronted with accelerated worldwide spreading of alien species. The accurate application of these metrics requires their further development by accounting for more or less strong effects the alien species exert on invaded aquatic ecosystems. 


\section{ACKNOWLEDGMENTS}

The study was supported by the Financial Mechanism of the European Economic Area (2009-2014), Programme BG03 Biodiversity and Ecosystem Services, Project ESENIASTOOLS, D-33-51/30.06.2015. 


\section{REFERENCES}

1. Arndt E., Fiedler S. and Böhme D., 2009 - Effects of invasive benthic macroinvertebrates on assessment methods of the EU Water Framework Directive, Hydrobiologia, 635, 309-320.

2. Atalah J., Kelly-Quinn M., Irvine K. and Crowe T. P., 2010 - Impacts of invasion by Dreissena polymorpha (Pallas, 1771) on the performance of macroinvertebrate assessment tools for eutrophication pressure in lakes, Hydrobiologia, 654, 237-251.

3. Bănăduc D., Rey D., Trichkova T., Lenhardt M. and Curtean-Bănăduc A., 2016 - The Lower Danube River-Danube Delta-North West Black Sea: A pivotal area of major interest for the past, present and future of its fish fauna - A short review, Science of the Total Environment, 545-546, 137-151.

4. Carlson R. E., 1977 - A trophic state index for lakes, Limnology and Oceanography, 22, 361-369.

5. De Winton M. D., Clayton J. S. and Edwards T., 2012 - Incorporating invasive weeds into a plant indicator method (LakeSPI) to assess lake ecological condition, Hydrobiologia, 691, 4758.

6. Hammer Ø., Harper D. A. T. and Ryan P. D., 2001 - PAST: Paleontological statistics software package for education and data analysis, Palaeontologia Electronica, 4, 1, 9, http://palaeoelectronica.org/2001_1/past/issue1_01.htm

7. Idrisi N., Mills E. L., Rudstam L. G. and Stewart D. J., 2001 - Impact of zebra mussels (Dreissena polymorpha) on the pelagic lower trophic levels of Oneida Lake, New York, Canadian Journal of Fisheries and Aquatic Sciences, 58, 1430-1441.

8. ISO 10260, 1992 - Water quality - Measurement of biochemical parameters - Spectrometric determination of the chlorophyll-a concentration, 1-4.

9. IUCN, 1999 - IUCN guidelines for the prevention of biodiversity loss due to biological invasions, Newsletter of the Species Survival Commission IUCN - The World Conservation Union, 31, 28-42.

10. Jarosiewicz A., Ficek D. and Zapadka T., 2011 - Eutrophication parameters and Carlson-type trophic state indices in selected Pomeranian lakes, Limnological Review, 11, 1, 15-23.

11. Kalchev R., Beshkova M., Botev I., Kalcheva H., Kozuharov D. and Trichkova T., 2013 - Effect of Dreissena polymorpha (Bivalvia: Dreissenidae) on physicochemical characteristics of Zhrebchevo Reservoir (Central Bulgaria), Comptes rendus de l'Academie bulgare des Sciences, 66, 11, 1571-1578.

12. Kalchev R., Beshkova M., Botev I., Kalcheva H., Kenderov L., Kozuharov D. and Trichkova T., 2014 - Relation of Transparency, Dissolved Oxygen and pH to Dreissena ssp. (Mollusca, Bivalvia) Occurrence in Bulgarian Standing Waters, Acta Zoologica Bulgarica, 66, 3, 389-397.

13. Letha J., Sabu J., Ramachandran K. K. and Sanalkumar S. P., 2011 - Trophic state index of a lake system using IRS (P6-LISS III) satellite imagery, Environmental Monitoring and Assessment, 177, 1, 575-592.

14. Qualls T. M., Dolan D. M., Reed T., Zorn M. E. and Kennedy J., 2007 - Analysis of the Impacts of the Zebra Mussel, Dreissena polymorpha, on Nutrients, Water Clarity, and the ChlorophyllPhosphorus Relationship in Lower Green Bay, Jurnal of Great Lakes Research, 33, 617-626.

15. Strayer D. L., Caraco N. F., Cole J. J., Findlay S. and Pace M. L., 1999 - Transformation of Freshwater Ecosystems by Bivalves, A case study of zebra mussels in the Hudson River, BioScience, 49, 1, 19-27.

16. Tosheva A. and Traykov I., 2012 - Abundance and Macrophyte Composition in Reservoirs with Different Trophic Status, BALWOIS 2012, Ohrid, Republic of Macedonia, 28 May, 2 June, 1-7. 